\title{
Target therapy in NSCLC patients: Relevant clinical agents and tumour molecular characterisation (Review)
}

\author{
PAOLA ULIVI $^{1}$, WAINER ZOLI ${ }^{1}$, LAURA CAPELLI ${ }^{1}$, ELISA CHIADINI ${ }^{2}$, \\ DANIELE CALISTRI $^{1}$ and DINO AMADORI ${ }^{1}$ \\ ${ }^{1}$ IRCCS Istituto Scientifico Romagnolo per lo Studio e la Cura dei Tumori (IRST), I-47014 Meldola; \\ ${ }^{2}$ Istituto Oncologico Romagnolo, I-47121 Forlì, Italy
}

Received October 26, 2012; Accepted February 26, 2013

DOI: $10.3892 / \mathrm{mco} .2013 .100$

\begin{abstract}
In recent years, a number of new agents that target specific molecular pathways in non-small cell lung cancer (NSCLC) have been investigated. Much effort has been focused on identifying specific markers that are predictive of treatment response, given that a tailored approach would maximise the therapeutic index and cost-effectiveness. Gefitinib and erlotinib are selective epidermal growth factor receptor (EGFR) tyrosine kinase inhibitors (EGFR-TKIs) and have produced good results in selected cases in terms of objective response rate and overall survival. At present, EGFR gene mutations are considered the most important predictors of clinical response to TKI therapy and tumour characterisation for these alterations is mandatory prior to any decision making. Echinoderm microtubule-like protein 4-anaplastic lymphoma kinase (EML4-ALK) translocation is another alteration capable of predicting the efficacy of anti-ALK agents, such as crizotinib. Moreover, emerging target agents, such as MET inhibitors, are likely to increase the amount of molecular characterisation required before a decision is made on treatment. The main limiting factor for adequate characterisation of metastatic NSCLC patients is the small quantity of tumour cells available for molecular analysis. In this study, we provided an overview of the most important and clinically relevant target agents in NSCLC patients as well as the most important mechanisms of resistance. The issue of the scant amount of biological samples available for analysis as well as alternative sampling approaches such as plasma- or serum-derived DNA were also examined.
\end{abstract}

Correspondence to: Ms Paola Ulivi, IRCCS Istituto Scientifico Romagnolo per lo Studio e la Cura dei Tumori (I.R.S.T.), Via Maroncelli 40, I-47014 Meldola (FC), Italy

E-mail: p.ulivi@irst.emr.it

Key words: non-small cell lung cancer, epidermal growth factor receptor tyrosine kinase inhibitors, echinoderm microtubule-like protein 4-anaplastic lymphoma kinase, MET, plasma/serum

\section{Contents}

1. Introduction

2. Clinically-relevant target drugs

3. Biological samples suitable for molecular characterisation

4. Conclusion

\section{Introduction}

Personalised treatment of cancer patients has become a reality in the last few years, with many drugs having been developed that target specific altered pathways. Concerning lung cancer, gefitinib and erlotinib are the first drugs to have demonstrated a good response in the treatment of patients with specific alterations in the EGFR gene $(1,2)$ rendering molecular characterisation of the tumour crucial prior to taking any decisions regarding therapy. Other drugs, such as crizotinib, have demonstrated that they produce a high response percentage in patients carrying the Echinoderm microtubule-like protein 4-anaplastic lymphoma kinase (EML4-ALK) translocation (3) and, more recently, in patients carrying the ROSI rearrangement (4) or MET amplification (5). Other target agents, such as MET inhibitors, are used in clinical trials, with the emergence of very promising results $(6,7)$.

The potential of utilizing molecular-targeted agents promotes analysis of the tumour for molecular alterations, in order to identify the best and most effective clinical treatment.

As lung cancer is diagnosed principally at advanced stages, the only biological material available for molecular analyses is derived from biopsy or needle aspirates, and is consequently lacking in quantity. Various technical improvements have been investigated in an attempt to obtain a greater amount of tumour cells.

In this review, the principal target agents that play a role in clinical practice, and the issues associated with the scarcity of tumour material required for molecular analyses were examined.

\section{Clinically-relevant target drugs}

EGFR-TKIs. Inhibition of the EGFR pathway with tyrosine kinase inhibitors (TKIs) has proven to be an effective treatment 
strategy for advanced non-small cell lung cancer (NSCLC) (8-10). TKIs are a class of drugs that act on the EGFR ATP-binding site, leading to the reversible blocking of downstream signalling pathway activation. In 2004, three different research groups showed that EGFR-TK domain mutations are associated with the response of NSCLC patients to gefitinib (11-13) or erlotinib (13). Somatic mutations are more frequently observed in patients with clinical features known to be associated with TKI sensitivity, such as female, adenocarcinoma histology, Asian ethnicity and non-smoking history. Following these initial observations, the majority of EGFR mutations have been reported to be found in the first four TK domain exons (14-19).

The most common EGFR-sensitising mutations, accounting for $85-90 \%$ of all those found in NSCLC, include exon 19 deletion (loss of codons 746-750, ELREA amino acid sequence) and exon 21 L858R substitution. The two mutations have been shown to enhance EGFR kinase activity and activate its downstream signalling, playing a pivotal role in NSCLC cell survival $(12,20)$. EGFR-TKIs are thought to neutralise the excessive survival signals to which cancer cells are 'addicted', leading to marked apoptosis $(20,21)$. Moreover, activating EGFR mutations have also been shown to enhance gefitinib affinity by increasing its activity (22). Point mutations in exon 18 (G719A/C) occur in $~ 5 \%$ of cases, which are associated with oncogenic potential in both cell culture and transgenic mouse studies $(14,18,23)$ and are also correlated with moderate TKI sensitivity $(23,24)$. A large number of studies has reported a significantly higher response rate (ORR $>80 \%)$, OS and TTP in patients with activating EGFR mutations compared to the wild-type individuals (ORR <10\%) (25-35).

In view of the results reported by the IPASS study (1), gefitinib (IRESSA, AstraZeneca Pharmaceuticals, Wilmington, DE, USA) was the first TKI approved by the European Medicines Agency (EMEA) for all lines of therapy in adults with locally advanced or metastatic NSCLC with activating EGFR tyrosine kinase mutations. Results of the EURTAC study (2) have led to the approval of Erlotinib (TARCEVA Genentech, Inc., South San Francisco, CA, and OSI Pharmaceuticals, Inc., Melville, NY, USA), already approved for the treatment of locally advanced or metastatic NSCLC following the failure of at least one prior chemotherapy regimen, for the first-line treatment of same stage patients carrying an EGFR mutation. Results of the phase II LUX-LUNG 2 study have demonstrated that afatinib, an irreversible ErbB family blocker of EGFR, HER2 and HER4, showed significant activity in EGFR mutated patients (36). Moreover, preliminary results from the randomised phase III study LUX-LUNG 3 have demonstrated that afatinib significantly prolonged PFS compared to pemetrexed/cisplatinum treatment (37).

Although EGFR-TKI treatment shows good response rates and PFS in NSCLC patients with EGFR gene mutations, acquired resistance to treatment almost always develops after a median time of approximately 10 months from the initiation of treatment. Different genotypic and histological mechanisms of resistance have therefore been suggested (38).

Approximately half of cancers that acquired resistance to EGFR-TKIs developed a secondary mutation in the EGFR kinase domain involving methionine to threonine substitution in codon $790(\mathrm{~T} 790 \mathrm{M})$ of exon 20 (39-41). This mutation is acquired through selective pressure during treatment, as it is rarely detected in tumours in untreated patients (40).

It has been demonstrated that T790M mutated cells show a growth disadvantage compared to wild-type cells, and these differential growth kinetics may be partly responsible for the 'flare' and 're-response' phenomenon observed in some patients with acquired response. Following the withdrawal of the selective pressure with a TKI, previously arrested TKI-sensitive cells can repopulate more rapidly compared with resistance cells and tumours may regain sensitivity to TKI (42). Additionally, in patients with acquired resistance, T790M has been found to be associated with a more indolent phenotype (43). Other less common mutations conferring modest resistance to EGFR-TKIs include the D761Y substitution and insertions in exon $20(44,45)$. The favourable prognosis associated with the presence of T790M on re-biopsy suggests that re-biopsies play an important clinical role in the management of these patients $(42,46)$.

As the acquisition of $7790 \mathrm{M}$ reduces the efficacy of ATP-competitive inhibitors, one strategy for preventing or overcoming EGFR-TKI resistance may be the use of agents that bind and inhibit EGFR through a distinct, non-ATP competitive mechanism, such as cetuximab or other EGFRtargeted antibodies or through the use of an irreversible inhibitor of EGFR, such as neratinib or afatinib. The combination of afatinib with cetuximab appears to have been the most promising approach in the treatment of patients with acquired resistance to EGFR-TKIs thus far (47).

Amplification of the MET receptor tyrosine kinase was observed in a further $15-20 \%$ of patients who underwent EGFR-TKI resistance. This amplification activates downstream intracellular signalling independently of EGFR and seems to occur independently of the T790M mutation (48). MET is a high-affinity tyrosine kinase receptor for hepatocyte growth factor (HGF). Interaction with its ligand has been shown to induce autophosphorylation at multiple tyrosine residues, including PI3K, in an ERBB3-dependent manner, inducing the activation of downstream pathways involved in cell growth, motility, survival, invasion and metastasis (49).

In addition to T790M and MET amplification, which are present in the majority of EGFR-TKI-resistant tumours, other phenotypic changes have been shown to be responsible for resistance mechanisms.

In $\sim 10-15 \%$ of EGFR-TKI-resistant cases, in the recurrent disease, a diagnosis of small-cell lung cancer (SCLC) was observed in patients, maintaining the original EGFR mutations and with the acquisition of neuroendocrine marker expression. These patients were also sensitive to a standard SCLC treatment (38), suggesting that in these cases, characterisation of the specific resistance mechanism can allow for the most appropriate choice of subsequent treatment as well.

Experiments performed in cell lines demonstrated an epithelial-to-mesenchymal transition (EMT) in developing EGFR-TKI resistance, with acquisition and loss of vimentin and E-cadherin expression, respectively. This observation has also been made in cancer patients, where this phenotypic change is associated with a more invasive phenotype (38). 
Anti-ALK therapy. Anaplastic lymphoma kinase (ALK) rearrangements were first identified as a fusion to a portion of the nucleophosmin (NPM) gene in $60 \%$ of anaplastic large cell lymphomas. ALK rearrangements in NSCLC were identified in late 2007, primarily as fusions to $\operatorname{EML} 4(50,51)$. The fusion protein has been identified in $\sim 3-7 \%$ of NSCLC patients and is primarily present in lung adenocarcinoma, in young patients and non-smokers or light smokers $(50,52)$. Moreover, this alteration seems to be mutually exclusive with that of EGFR and KRAS. Most of the identified EML4-ALK fusion proteins have been shown to be oncogenic in both in vitro and in vivo systems $(50,53)$. Pre-clinical and clinical studies have shown that cancer cells harbouring EML4-ALK or other ALK abnormalities are extremely sensitive to ALK inhibitors $(54,55)$. The first clinically available TKI targeting ALK, crizotinib (PF-02341066), showed marked antitumour activity in a phase I study in patients with advanced ALK-positive NSCLC (3). A notable overall 57\% response rate and 33\% stable disease were observed. These excellent results led to the accelerated approval of the drug in the USA.

Additionally, with regard to crizotinib, several mechanisms of resistance have been demonstrated that occurred following approximately 12 months of treatment.

Acquired resistance to crizotinib was associated with secondary mutations in the $A L K$ gene. These mutations either involve the 'gatekeeper' residue (L1196) or sites at a distance from crizotinib binding (F1174L and C1156Y) (56,57). Other mechanisms, such as the activation of HER family signalling, have been demonstrated as ALK-TKI-resistant (58). The cytotoxic activity of crizotinib has also been demonstrated against tumours carrying the ROS1 rearrangement $(4,59)$ and $M E T$ amplification (5).

Anti-MET agents. MET amplification is a rare de novo event in NSCLC patients (60), whereas it is a common mechanism of EGFR-TKI-induced resistance. Numerous target agents have been studied with the intention of inhibiting MET activity and the results for some of these agents are promising.

Tivantinib (ARQ 197) is currently in a phase III trial (marquee) based on a successful randomised phase II study (erlotinib \pm tivantinib) (6) in which activity has been demonstrated, particularly in KRAS-mutated tumours. MetMAb (Hoffmann-LaRoche, Mississauga, ON, Canada), a monovalent anti-Met monoclonal antibody, has produced significant results in a randomised phase II trial (OAM4558g). In this study, MetMAb, in association with erlotinib, increased PFS and OS significantly compared to erlotinib alone, and the principal predictive factor was the expression of MET evaluated by immunohistochemistry (61). MET is likely to be the next major biomarker in metastatic NSCLC, given the speed with which the different drugs are applied in the clinic.

\section{Biological samples suitable for molecular characte- risation}

Of note for the molecular characterisation of NSCLC patients is that biological material for molecular analyses is not always sufficient or available for inoperable stage IIIB and IV tumours.

The gold standard for molecular analysis is paraffinembedded histological slides derived from a histological sample, such as a biopsy, where a tumour cell selection has been performed in order to identify a section area with at least $50 \%$ of tumour cells. Subsequently, false-negative results may be avoided as non-tumour cells around the tumour may undergo DNA extraction together with tumour cells, leading to contamination of the results.

Approximately one-third of primary NSCLC diagnoses are performed on cytological samples (62-64) and usually no other biopsy materials are available for molecular analyses. Efforts have therefore been focused on detection of EGFR mutations in cytological samples and the results of several studies have demonstrated that cytological material is suitable and reliable for EGFR mutation analysis (65-70), such as that for the EML4-ALK FISH test (68). Specifically, paraffin-embedded histological or cytological sections could, compared to cytological smears, result in truncated cells and nuclei, producing more DNA fragmentation and a consequent possible false number of gene copies.

However, cytological material is usually the only available diagnostic biologic material and it is the only biologic material available in Pathology archives. Its destruction therefore is likely to pose a problem. Moreover, use of only one cytological slide would be insufficient for performing all the necessary molecular analyses.

Authors of the present study as well as other investigators (68-70) have demonstrated that EGFR mutation analysis may be performed on a small number of tumour cells (20-30 cells) isolated from a cytological slide, enabling the remaining material to be archived or used for other molecular analyses such as the EML4-ALK FISH test.

We have also demonstrated that EGFR mutation analysis can be performed subsequent to the EML4-ALK FISH test (71). Tumour cells can be scraped off the slide after the FISH analysis and be subjected to DNA extraction and EGFR mutation analysis. Thus, the same tumour cells can be used for two different molecular analyses.

The increase in molecular characterisation that has become crucial for the clinical management of patients has led to a search for new approaches to optimise the use of available biological samples. The increasing importance of MET inhibitor agents is likely to require $M E T$ amplification characterisation, potentially adding to the EGFR and EML4-ALK analyses that are now required.

A non-invasive approach able to overcome the scarcity of tumour material is the analysis of DNA extracted from plasma/serum or from circulating tumour cells (CTCs). It has been demonstrated that free-tumour-derived DNA levels in plasma or serum are significantly higher in lung cancer patients compared to healthy donors $(72,73)$. This finding may be explained by the presence of necrotic cells sloughed from primary tumour or CTCs, which possess identical genetic lesions.

Kimura et al were the first to report the detection of EGFR mutations in serum (74,75). In their study, the tumour and serum samples from 42 patients were analysed. EGFR mutations were detected in 8 tumour and in 7 serum samples, showing a high concordance between tumour and serum (75). Subsequent studies have attempted to confirm these results in a larger case series (75-89). Using different methodologies, results of the majority of those studies identified identical 
Table I. Correlation between EGFR mutation status in paired plasma and tumour samples.

\begin{tabular}{|c|c|c|c|c|}
\hline Author, year (ref.) & $\begin{array}{l}E G F R \text {-mutated } \\
\text { tumours (n) }\end{array}$ & $\begin{array}{l}\text { Biological } \\
\text { material }\end{array}$ & Methodology & $\begin{array}{c}\text { Mutations in } \\
\text { paired samples } \\
\%(\mathrm{n})\end{array}$ \\
\hline Kimura et al, 2007 (74) & 8 & Serum & SARMS & $75(6 / 8)$ \\
\hline Maheswaran et al, 2008 (75) & 18 & $\begin{array}{c}\text { Plasma } \\
\text { CTC }\end{array}$ & $\begin{array}{l}\text { SARMS } \\
\text { SARMS }\end{array}$ & $\begin{array}{c}39(7 / 18) \\
94(17 / 18)\end{array}$ \\
\hline Yung et al, 2009 (76) & 12 & Plasma & Digital PCR & $92(11 / 12)$ \\
\hline Kuang et al, 2009 (77) & 30 & Plasma & SARMS and WAVE/Surveyor & $70(21 / 30)$ \\
\hline He et al, 2009 (78) & 18 & Plasma & Mutant-enriched PCR & $94.4(17 / 18)$ \\
\hline Bai et al, 2009 (79) & 77 & Plasma & DHPLC & $82(63 / 77)$ \\
\hline Mack et al, 2009 (80) & 7 & Plasma & SARMS & $71(5 / 7)$ \\
\hline Jiang et al, 2011 (83) & 18 & Serum & Mutant enriched PCR & $78(14 / 18)$ \\
\hline Brevet et al, 2011(84) & 31 & Plasma & Mass spectrometry & $61(19 / 31)$ \\
\hline Taniguchi et al, 2011 (85) & 44 & Plasma & BEAMing & $73(32 / 44)$ \\
\hline Chen et al, 2012 (86) & 30 & Plasma & PNA-LNA PCR & $83(25 / 30)$ \\
\hline Nakamura et al, 2012 (87) & 39 & Plasma & WIP-QP & $39(15 / 39)$ \\
\hline Goto et al, 2012 (88) & 51 & Serum & SARMS & $43(22 / 51)$ \\
\hline
\end{tabular}

CTC, circulating tumoural cells; SARMS, scorpion amplification refractory mutation system; DHPLC, denaturing high-performance liquid chromatography; BEAMing, beads, emulsion, amplification and magnetics; WIP-QP, wild inhibiting polymerase chain reaction and quenched probe system; PNA-LNA PCR, peptide nucleic acid-locked nucleic acid polymerase chain reaction.

serum/plasma, with tissue EGFR mutations being reported in $>70 \%$ of patients (74-89) (Table I).

Moreover, in some of these studies, EGFR mutations were found in the plasma but not in the corresponding tumour tissue (80). In their study, Bai et al (80) reported that of 77 patients with primary tumour with an EGFR mutations, 63 exhibited identical alterations in the matched plasma. Moreover, $7 \%$ of patients with plasma mutations had no detectable alterations in the corresponding primary tumours, while $6 \%$ of patients with tumour mutations had no detectable EGFR alterations in the corresponding plasma. The authors attempted to explain this apparent inconsistency in terms of the heterogeneity of genetic tumour abnormalities, where tumour cells may or may not carry the mutation. A recent study has demonstrated a high discordance rate among multiple pulmonary nodules in terms of EGFR mutation, emphasizing the problem of tumour heterogeneity (90) and suggesting that CTC or circulating DNA analyses are crucial in the identification of the presence of mutations and tumour heterogeneity.

The lower tumour cell content in some of the samples may also contribute to the lack of detectable mutations in some tumour tissues in which the corresponding plasma was mutated.

Plasma DNA analysis has also been used to monitor patients during gefitinib treatment, for example, to characterise secondary mutations, such as the T790M alteration $(78,86)$. This may be significant in view of the characterisation of the molecular mechanisms of resistance after TKI treatment in order to select the best subsequent personalised treatment.

The possibility of characterising EGFR status in CTCs (76), with high levels of sensitivity has also been demonstrated.
However, the technology of CTC enrichment remains to be standardised and generalised, although in recent years efforts have been made to investigate CTC detection and characterisation (91-94).

Nevertheless, the scarcity of materials obtained from the primary tumour tissue of advanced-stage lung cancer patients and from biopsy or cytological samples highlights the potential clinical importance of plasma/serum or CTCs as a surrogate biological sample for genetic analysis.

\section{Conclusion}

EGFR mutations and EML4-ALK translocation analyses are the most clinically relevant alterations that can dictate personalised treatment for NSCLC patients, with EGFRTKIs or anti-ALK agents, respectively. The growing number of other promising target agents, including MET inhibitors, makes it likely that MET or other markers may aid in decision making. The scarcity of tumour samples available for molecular analysis should be addressed, and different technological approaches may allow for the optimal use of the material, in order to attempt to perform a higher amount of molecular characterisation with a minimal amount of material. Improvement in terms of the sensitivity of molecular biology technologies may therefore prove useful. The possibility of performing molecular characterisations on small amounts of biological material is an important issue, considering the possibility of performing a re-characterisation of tumours following TKI resistance, in order to define the best second-line personalised treatment in view of the specific induced resistance mechanism. 


\section{Acknowledgements}

The authors would like to thank Professor Rosella Silvestrini for her invaluable scientific contribution and Ursula Elbling for editing the manuscript.

\section{References}

1. Mok TS, Wu YL, Thongprasert S, Yang CH, Chu DT, Saijo N, Sunpaweravong P, Han B, Margono B, Ichinose Y, et al: Gefitinib or carboplatin-paclitaxel in pulmonary adenocarcinoma. N Engl J Med 361: 947-957, 2009.

2. Rosell R, Carcereny E, Gervais R, Vergnenegre A, Massuti B, Felip E, Palmero R, Garcia-Gomez R, Pallares C, Sanchez JM, et al: Erlotinib versus standard chemotherapy as first-line treatment for European patients with advanced EGFR mutationpositive non-small-cell lung cancer (EURTAC): a multicentre, open-label, randomised phase 3 trial. Lancet Oncol 13: 239-246, 2012.

3. Kwak EL, Bang YJ, Camidge DR, Shaw AT, Solomon B, Maki RG, Ou SH, Dezube BJ, Jänne PA, Costa DB, et al: Anaplastic lymphoma kinase inhibition in non-small-cell lung cancer. N Engl J Med 363: 1693-1703, 2010.

4. Bergethon K, Shaw AT, Ou SH, Katayama R, Lovly CM, McDonald NT, Massion PP, Siwak-Tapp C, Gonzalez A, Fang R, et al: ROS1 rearrangements define a unique molecular class of lung cancers. J Clin Oncol 30: 863-870, 2012.

5. Ou SH, Kwak EL, Siwak-Tapp C, Dy J, Bergethon K, Clark JW, Camidge DR, Solomon BJ, Maki RG, Bang YJ, et al: Activity of crizotinib (PF02341066), a dual mesenchymal-epithelial transition (MET) and anaplastic lymphoma kinase (ALK) inhibitor, in a non-small cell lung cancer patient with de novo MET amplification. J Thorac Oncol 6: 942-946, 2011.

6. Sequist LV, von Pawel J, Garmey EG, Akerley WL, Brugger W, Ferrari D, Chen Y, Costa DB, Gerber DE, Orlov S, et al: Randomized phase II study of erlotinib plus tivantinib versus erlotinib plus placebo in previously treated non-small-cell lung cancer. J Clin Oncol 29: 3307-3315, 2011.

7. Surati M, Patel P, Peterson A and Salgia R: Role of MetMAb (OA-5D5) in c-MET active lung malignancies. Expert Opin Biol Ther 11: 1655-1662, 2011.

8. Scagliotti GV: Potential role of multi-targeted tyrosine kinase inhibitors in non-small-cell lung cancer. Ann Oncol 18 (Suppl 10): $\mathrm{x} 32-\mathrm{x} 41,2007$.

9. Gettinger S: Targeted therapy in advanced non-small-cell lung cancer. Semin Respir Crit Care Med 29: 291-301, 2008.

10. Rosell R, Viteri S, Molina MA, Benlloch S and Taron M: Epidermal growth factor receptor tyrosine kinase inhibitors as first-line treatment in advanced nonsmall-cell lung cancer. Curr Opin Oncol 22: 112-120, 2010.

11. Paez JG, Jänne PA, Lee JC, Tracy S, Greulich H, Gabriel S, Herman P, Kaye FJ, Lindeman N, Boggon TJ, et al: EGFR mutations in lung cancer: correlation with clinical response to gefitinib therapy. Science 304: 1497-1500, 2004.

12. Lynch TJ, Bell DW, Sordella R, Gurubhagavatula S, Okimoto RA, Brannigan BW, Harris PL, Haserlat SM, Supko JG, Haluska FG, Louis DN, Christiani DC, et al: Activating mutations in the epidermal growth factor receptor underlying responsiveness of non-small-cell lung cancer to gefitinib. N Engl J Med 350: 2129-2139, 2004

13. Pao W, Miller V, Zakowski M, Doherty J, Politi K, Sarkaria I, Singh B, Heelan R, Rusch V, Fulton L, et al: EGF receptor gene mutations are common in lung cancers from 'never smokers' and are associated with sensitivity of tumors to gefitinib and erlotinib. Proc Natl Acad Sci USA 101: 13306-13311, 2004.

14. Pao W and Miller VA: Epidermal growth factor receptor mutations, small-molecule kinase inhibitors, and non-small-cell lung cancer: current knowledge and future directions. J Clin Oncol 23: 2556-2568, 2005.

15. Riely GJ, Politi KA, Miller VA and Pao W: Update on epidermal growth factor receptor mutations in non-small cell lung cancer. Clin Cancer Res 12: 7232-7241, 2006.

16. Shigematsu H, Lin L, Takahashi T, Nomura M, Suzuki M, Wistuba II, Fong KM, Lee H, Toyooka S, Shimizu N, et al: Clinical and biological features associated with epidermal growth factor receptor gene mutations in lung cancers. J Natl Cancer Inst 97: 339-346, 2005.
17. Marchetti A, Martella C, Felicioni L, Barassi F, Salvatore S, Chella A, Camplese PP, Iarussi T, Mucilli F, Mezzetti A, et al: EGFR mutations in non-small-cell lung cancer: analysis of a large series of cases and development of a rapid and sensitive method for diagnostic screening with potential implications on pharmacologic treatment. J Clin Oncol 23: 857-865, 2005.

18. Sharma SV, Bell DW, Settleman J and Haber DA: Epidermal growth factor receptor mutations in lung cancer. Nat Rev Cancer 7: 169-181, 2007.

19. Dahabreh IJ, Linardou H, Siannis F, Kosmidis P, Bafaloukos D and Murray S: Somatic EGFR mutation and gene copy gain as predictive biomarkers for response to tyrosine kinase inhibitors in non-small cell lung cancer. Clin Cancer Res 16: 291-303, 2010.

20. Sordella R, Bell DW, Haber DA and Settleman J: Gefitinibsensitizing EGFR mutations in lung cancer activate anti-apoptotic pathways. Science 305: 1163-1167, 2004.

21. Tracy S, Mukohara T, Hansen M, Meyerson M, Johnson BE and Jänne PA: Gefitinib induces apoptosis in the EGFRL858R non-small-cell lung cancer cell line H3255. Cancer Res 64: 7241-7244, 2004.

22. Mulloy R, Ferrand A, Kim Y, Sordella R, Bell DW, Haber DA, Anderson KS and Settleman J: Epidermal growth factor receptor mutants from human lung cancers exhibit enhanced catalytic activity and increased sensitivity to gefitinib. Cancer Res 67: 2325-2330, 2007.

23. Greulich H, Chen TH, Feng W, Jänne PA, Alvarez JV, Zappaterra M, Bulmer SE, Frank DA, Hahn WC, Sellers WR and Meyerson M: Oncogenic transformation by inhibitor-sensitive and -resistant EGFR mutants. PLoS Med 2: e313, 2005.

24. Jiang J, Greulich H, Janne PA, Sellers WR, Meyerson M and Griffin JD: Epidermal growth factor-independent transformation of $\mathrm{Ba} / \mathrm{F} 3$ cells with cancer-derived epidermal growth factor receptor mutants induces gefitinib-sensitive cell cycle progression. Cancer Res 65: 8968-8974, 2005.

25. Sequist LV, Bell DW, Lynch TJ and Haber DA: Molecular predictors of response to epidermal growth factor receptor antagonists in non-small-cell lung cancer. J Clin Oncol 25: 587-595, 2007.

26. Gupta R, Dastane AM, McKenna R Jr and Marchevsky AM: The predictive value of epidermal growth factor receptor tests in patients with pulmonary adenocarcinoma: review of current 'best evidence' with meta-analysis. Hum Pathol 40: 356-365, 2009.

27. Takano T, Ohe Y, Sakamoto H, Tsuta K, Matsuno Y, Tateishi U, Yamamoto S, Nokihara H, Yamamoto N, Sekine I, et al: Epidermal growth factor receptor gene mutations and increased copy numbers predict gefitinib sensitivity in patients with recurrent non-small-cell lung cancer. J Clin Oncol 23: 6829-6837, 2005.

28. Bell DW, Lynch TJ, Haserlat SM, Harris PL, Okimoto RA, Brannigan BW, Sgroi DC, Muir B, Riemenschneider MJ, Iacona RB, et al: Epidermal growth factor receptor mutations and gene amplification in non-small-cell lung cancer: molecular analysis of the IDEAL/INTACT gefitinib trials. J Clin Oncol 23: 8081-8092, 2005.

29. Sone T, Kasahara K, Kimura H, Nishio K, Mizuguchi M, Nakatsumi Y, Shibata K, Waseda Y, Fujimura M and Nakao S: Comparative analysis of epidermal growth factor receptor mutations and gene amplification as predictors of gefitinib efficacy in Japanese patients with nonsmall cell lung cancer. Cancer 109: 1836-1844, 2007.

30. Cappuzzo F, Ligorio C, Jänne PA, Toschi L, Rossi E, Trisolini R, Paioli D, Holmes AJ, Magrini E, Finocchiaro G, et al: Prospective study of gefitinib in epidermal growth factor receptor fluorescence in situ hybridization-positive/phospho-Akt-positive or never smoker patients with advanced non-small-cell lung cancer: the ONCOBELL trial. J Clin Oncol 25: 2248-2255, 2007.

31. Hirsch FR, Varella-Garcia M, Cappuzzo F, McCoy J, Bemis L, Xavier AC, Dziadziuszko R, Gumerlock P, Chansky K, West $\mathrm{H}$, et al: Combination of EGFR gene copy number and protein expression predicts outcome for advanced non-smallcell lung cancer patients treated with gefitinib. Ann Oncol 18: 752-760, 2007.

32. Ahn MJ, Park BB, Ahn JS, Kim SW, Kim HT, Lee JS, Kang JH, Cho JY, Song HS, Park SH, et al: Are there any ethnic differences in molecular predictors of erlotinib efficacy in advanced non-small cell lung cancer? Clin Cancer Res 14: 3860-3866, 2008.

33. Dongiovanni D, Daniele L, Barone C, Dongiovanni V, Fissore C, Sapino A, Macrì L, Bussolati G, Buffoni L, Gaspari F, et al: Gefitinib (ZD1839): therapy in selected patients with non-small cell lung cancer (NSCLC)? Lung Cancer 61: 73-81, 2008. 
34. Schneider CP, Heigener D, Schott-von-Römer K, Gütz S, Laack E, Digel W, Guschall WR, Franke A, Bodenstein H, Schmidtgen C and Reck M: Epidermal growth factor receptor-related tumor markers and clinical outcomes with erlotinib in non-small cell lung cancer: an analysis of patients from German centers in the TRUST study. J Thorac Oncol 3: 1446-1453, 2008.

35. Taron M, Ichinose Y, Rosell R, Mok T, Massuti B, Zamora L, Mate JL, Manegold C, Ono M, Queralt C, et al: Activating mutations in the tyrosine kinase domain of the epidermal growth factor receptor are associated with improved survival in gefitinib-treated chemorefractory lung adenocarcinomas. Clin Cancer Res 11: 5878-5885, 2005.

36. Yang JC, Shih JY, Su WC, Hsia TC, Tsai CM, Ou SH, Yu CJ, Chang GC, Ho CL, Sequist LV, et al: Afatinib for patients with lung adenocarcinoma and epidermal growth factor receptor mutations (LUX-Lung 2): a phase 2 trial. Lancet Oncol 13: 539-548, 2012

37. Chih-Hsin Yang J, Schuler MH,Yamamoto N, O'Byrne KJ, Vera H, Mok T, Geater SL, Orlov SV, Tsai CM, Boyer MJ, et al: LUX-Lung 3: A randomized, open-label, phase III study of afatinib versus pemetrexed and cisplatin as first-line treatment for patients with advanced adenocarcinoma of the lung harboring EGFR-activating mutations. Presented at 2012 American Society of Clincal Oncology (ASCO) Annual Meeting. (abs. LBA7500), 2012. http://www.asco.org/ASCOv2/Meetings/Abstracts.

38. Sequist LV, Waltman BA, Dias-Santagata D, Digumarthy S, Turke AB, Fidias P, Bergethon K, Shaw AT, Gettinger S, Cosper AK, et al: Genotypic and histological evolution of lung cancers acquiring resistance to EGFR inhibitors. Sci Trans Med 3: 75ra26, 2011.

39. Kobayashi S, Boggon TJ, Dayaram T, Jänne PA, Kocher O, Meyerson M, Johnson BE, Eck MJ, Tenen DG and Halmos B: EGFR mutation and resistance of non-small-cell lung cancer to gefitinib. N Engl J Med 352: 786-792, 2005.

40. Pao W, Miller VA, Politi KA, Riely GJ, Somwar R, Zakowski MF, Kris MG and Varmus H: Acquired resistance of lung adenocarcinomas to gefitinib or erlotinib is associated with a second mutation in the EGFR kinase domain. PLoS Med 2: e73, 2005

41. Kosaka T, Yatabe Y, Endoh H, Yoshida K, Hida T, Tsuboi M, Tada H, Kuwano $\mathrm{H}$ and Mitsudomi T: Analysis of epidermal growth factor receptor gene mutation in patients with non-small cell lung cancer and acquired resistance to gefitinib. Clin Cancer Res 12: 5764-5769, 2006.

42. Oxnard GR, Arcila ME, Chmielecki J, Ladanyi M, Miller VA and Pao W: New strategies in overcoming acquired resistance to epidermal growth factor receptor tyrosine kinase inhibitors in lung cancer. Clin Cancer Res 17: 5530-5537, 2011.

43. Oxnard GR, Arcila ME, Sima CS, Riely GJ, Chmielecki J, Kris MG, Pao W, Ladanyi M and Miller VA: Acquired resistance to EGFR tyrosine kinase inhibitors in EGFR-mutant lung cancer: distinct natural history of patients with tumors harboring the T790M mutation. Clin Cancer Res 17: 1616-1622, 2011.

44. Sasaki H,Endo K, Takada M,Kawahara M,Kitahara N, Tanaka H, Okumura M, Matsumura A, Iuchi K, Kawaguchi T, et al: EGFR exon 20 insertion mutation in Japanese lung cancer. Lung Cancer 58: 324-328, 2007.

45. Balak MN, Gong Y, Riely GJ, Somwar R, Li AR, Zakowski MF, Chiang A, Yang G, Ouerfelli O, Kris MG, et al: Novel D761Y and common secondary T790M mutations in epidermal growth factor receptor-mutant lung adenocarcinomas with acquired resistance to kinase inhibitors. Clin Cancer Res 12: 6494-6501, 2006.

46. Arcila ME, Oxnard GR, Nafa K, Riely GJ, Solomon SB, Zakowski MF, Kris MG, Pao W, Miller VA and Ladanyi M: Rebiopsy of lung cancer patients with acquired resistance to EGFR inhibitors and enhanced detection of the T790M mutation using a locked nucleic acid-based assay. Clin Cancer Res 17: 1169-1180, 2011.

47. Janjigian YY, Groen HJ, Horn L, Smit EF, Fu Y, Wang F, Shahidi M, Denis LJ, Pao W and Miller VA: Activity and tolerability of afatinib (BIBW 2992) and cetuximab in NSCLC patients with acquired resistance to erlotinib or gefitinib. Presented at 2011 American Society of Clincal Oncology (ASCO) Annual Meeting. (abs. 7525), 2011. http://www.asco. org/ASCOv2/Meetings/Abstracts.

48. Engelman JA, Zejnullahu K, Mitsudomi T, Song Y, Hyland C, Park JO, Lindeman N, Gale CM, Zhao X, Christensen J, et al: MET amplification leads to gefitinib resistance in lung cancer by activating ERBB3 signaling. Science 316: 1039-1043, 2007.
49. Birchmeier C, Birchmeier W, Gherardi E and Vande Woude GF: Met, metastasis, motility and more. Nat Rev Mol Cell Biol 4: 915-925, 2003

50. Soda M, Choi YL, Enomoto M, Takada S, Yamashita Y, Ishikawa S, Fujiwara S, Watanabe H, Kurashina K, Hatanaka H, et al: Identification of the transforming EML4-ALK fusion gene in non-small-cell lung cancer. Nature 448: 561-566, 2007.

51. Rikova K, Guo A,Zeng Q, Possemato A, Yu J, Haack H, Nardone J, Lee K, Reeves C, Li Y, et al: Global survey of phosphotyrosine signaling identifies oncogenic kinases in lung cancer. Cell 131: 1190-1203, 2007

52. Shaw AT, Yeap BY, Mino-Kenudson M, Digumarthy SR, Costa DB, Heist RS, Solomon B, Stubbs H, Admane S, McDermott U, et al: Clinical features and outcome of patients with non-small-cell lung cancer who harbor EML4-ALK. J Clin Oncol 27: 4247-4253, 2009.

53. Takeuchi K, Choi YL, Soda M, Inamura K, Togashi Y, Hatano S, Enomoto M, Takada S, Yamashita Y, Satoh Y, et al: Multiplex reverse transcription-PCR screening for EML4-ALK fusion transcripts. Clin Cancer Res 14: 6618-6624, 2008.

54. Koivunen JP, Mermel C, Zejnullahu K, Murphy C, Lifshits E, Holmes AJ, Choi HG, Kim J, Chiang D, Thomas R, et al: EML4-ALK fusion gene and efficacy of an ALK kinase inhibitor in lung cancer. Clin Cancer Res 14: 4275-4283, 2008.

55. McDermott U, Iafrate AJ, Gray NS, Shioda T, Classon M, Maheswaran S, Zhou W, Choi HG, Smith SL, Dowell L, et al: Genomic alterations of anaplastic lymphoma kinase may sensitize tumors to anaplastic lymphoma kinase inhibitors. Cancer Res 68: 3389-3395, 2008

56. Sasaki T, Okuda K, Zheng W, Butrynski J, Capelletti M, Wang L, Gray NS, Wilner K, Christensen JG, Demetri G, et al: The neuroblastoma-associated F1174L ALK mutation causes resistance to an ALK kinase inhibitor in ALK-translocated cancers. Cancer Res 70: 10038-10043, 2010.

57. Choi YL, Soda M, Yamashita Y, Ueno T, Takashima J, Nakajima T, Yatabe Y, Takeuchi K, Hamada T, Haruta H, et al: EML4-ALK mutations in lung cancer that confer resistance to ALK inhibitors. N Engl J Med 363: 1734-1739, 2010.

58. Tanizaki J, Okamoto I, Okabe T, Sakai K, Tanaka K, Hayashi H, Kaneda H, Takezawa K, Kuwata K, Yamaguchi H, et al: Activation of HER family signaling as a mechanism of acquired resistance to ALK inhibitors in EML4-ALK-positive non-small cell lung cancer. Clin Cancer Res: Jul 27, 2012 (E-pub ahead of print).

59. Yasuda H, de Figueiredo-Pontes LL, Kobayashi S and Costa DB: Preclinical rationale for use of the clinically available multitargeted tyrosine kinase inhibitor crizotinib in ROS1-translocated lung cancer. J Thorac Oncol 7: 1086-1090, 2012.

60. Cappuzzo F, Jänne PA, Skokan M, Finocchiaro G, Rossi E, LigorioC, Zucali PA, Terracciano L, Toschi L, Roncalli M, et al: MET increased gene copy number and primary resistance to gefitinib therapy in non-small-cell lung cancer patients. Ann Oncol 20: 298-304, 2009.

61. Spigel DR, Ervin TJ, Ramlau R, Daniel DB, Goldschmidt JH, Blumenschein GR, Krzakowski MJ, Robinet G, ClementDuchene C, Barlesi F, et al: Final efficacy results from OAM4558g, a randomized phase II study evaluating MetMAb or placebo in combination with erlotinib in advanced NSCLC. Presented at 2011 American Society of Clinical Oncology (ASCO) Annual Meeting. (abs. 7505), 2011. http://www.asco. org/ASCOv2/Meetings/Abstracts.

62. Gu P, Zhao YZ, Jiang LY, Zhang W, Xin Y and Han BH: Endobronchial ultrasound-guided transbronchial needle aspiration for staging of lung cancer: a systematic review and meta-analysis. Eur J Cancer 45: 1389-1396, 2009.

63. Annema JT, Versteegh MI, Veseliç M, Welker L, Mauad T, Sont JK, Willems LN and Rabe KF: Endoscopic ultrasound added to mediastinoscopy for preoperative staging of patients with lung cancer. JAMA 294: 931-936, 2005.

64. Tournoy KG, Rintoul RC, van Meerbeeck JP, Carroll NR, Praet M, Buttery RC, van Kralingen KW, Rabe KF and Annema JT: EBUS-TBNA for the diagnosis of central parenchymal lung lesions not visible at routine bronchoscopy. Lung Cancer 63: 45-49, 2009.

65. Chen JT, Lane MA and Clark DP: Inhibitors of the polymerase chain reaction in Papanicolaou stain. Removal with a simple destaining procedure. Acta Cytol 40: 873-877, 1996.

66. Smith GD, Chadwick BE, Willmore-Payne Ca and Bentz JS: Detection of epidermal growth factor receptor gene mutations in cytology specimens from patients with non-small cell lung cancer utilising high-resolution melting amplicon analysis. J Clin Pathol 61: 487-493, 2008 
67. Smouse JH, Cibas ES, Jänne PA, Joshi VA, Zou KH and Lindeman NI: EGFR mutations are detected comparably in cytologic and surgical pathology specimens of nonsmall cell lung cancer. Cancer 117: 67-72, 2009.

68. Savic S, Tapia C, Grilli B, Rufle A, Bihl MP, de Vito Barascud A, Herzog M, Terracciano L, Baty F and Bubendorf L: Comprehensive epidermal growth factor receptor gene analysis from cytological specimens of non-small-cell lung cancers. Br J Cancer 98: 154-160, 2008.

69. Ulivi P, Romagnoli M, Chiadini E, Casoni GL, Capelli L, Gurioli C, Zoli W, Saragoni L, Dubini A, Tesei A, Amadori D and Poletti V: Assessment of EGFR and K-ras mutations in fixed and fresh specimens from transesophageal ultrasound-guided fine needle aspiration in non-small cell lung cancer patients. Int J Oncol 41: 147-152, 2012.

70. Ulivi P, Zoli W, Chiadini E, Capelli L, Candoli P, Calistri D, Silvestrini R and Puccetti M: EGFR and K-ras mutations in cytologic samples from fine-needle aspirates in NSCLC patients. Eur Respir J 40: 267-269, 2012.

71. Ulivi P, Puccetti M, Capelli L, Chiadini E, Bravaccini S, Calistri D, Zoli W, Amadori D and Candoli P. Molecular determinations of EGFR and EML4-ALK on a single slide of NSCLC tissue. J Clin Pathol (In press).

72. Sozzi G, Conte D, Leon M, Ciricione R, Roz L, Ratcliffe C, Roz E, Cirenei N, Bellomi M, Pelosi G, Pierotti MA and Pastorino U: Quantification of free circulating DNA as a diagnostic marker in lung cancer. J Clin Oncol 21: 3902-3908, 2003.

73. Ulivi P, Mercatali L, Zoli W, Dell'amore D, Poletti V, Casoni GL, Scarpi E, Flamini E, Amadori D and Silvestrini R: Serum free DNA and COX-2 mRNA expression in peripheral blood for lung cancer detection. Thorax 63: 843-844, 2008.

74. Kimura H, Kasahara K, Kawaishi M, Kunitoh H, Tamura T, Holloway B and Nishio K: Detection of epidermal growth factor receptor mutations in serum as a predictor of the response to gefitinib in patients with non-small-cell lung cancer. Clin Cancer Res 12: 3915-3921, 2006.

75. Kimura H, Suminoe M, Kasahara K, Sone T, Araya T, Tamori S Koizumi F, Nishio K, Miyamoto K, Fujimura M and Nakao S: Evaluation of epidermal growth factor receptor mutation status in serum DNA as a predictor of response to gefitinib (IRESSA). Br J Cancer 97: 778-784, 2007.

76. Maheswaran S, Sequist LV, Nagrath S, Ulkus L, Brannigan B, Collura CV, Inserra E, Diederichs S, Iafrate AJ, Bell DW, et al: Detection of mutations in EGFR in circulating lung-cancer cells. N Engl J Med 359: 366-377, 2008.

77. Yung TK, Chan KC, Mok TS, Tong J, To KF and Lo YM: Single-molecule detection of epidermal growth factor receptor mutations in plasma by microfluidics digital PCR in non-small cell lung cancer patients. Clin Cancer Res 15: 2076-2084, 2009.

78. Kuang Y, Rogers A, Yeap BY, Wang L, Makrigiorgos M Vetrand K, Thiede S, Distel RJ and Jänne PA: Noninvasive detection of EGFR T790M in gefitinib or erlotinib resistant non-small cell lung cancer. Clin Cancer Res 15: 2630-2636, 2009.

79. He C, Liu M, Zhou C, Zhang J, Ouyang M, Zhong N and Xu J: Detection of epidermal growth factor receptor mutations in plasma by mutant-enriched PCR assay for prediction of the response to gefitinib in patients with non-small-cell lung cancer. Int J Cancer 125: 2393-2399, 2009.

80. Bai H, Mao L, Wang HS, Zhao J, Yang L, An TT, Wang X, Duan CJ, Wu NM, Guo ZQ, et al: Epidermal growth factor receptor mutations in plasma DNA samples predict tumor response in Chinese patients with stages IIIB to IV non-smallcell lung cancer. J Clin Oncol 27: 2653-2659, 2009.

81. Mack PC, Holland WS, Burich RA, Sangha R, Solis LJ, Li Y, Beckett LA, Lara PN Jr, Davies AM and Gandara DR: EGFR mutations detected in plasma are associated with patient outcomes in erlotinib plus docetaxel-treated non-small cell lung cancer. J Thorac Oncol 4: 1466-1472, 2009.
82. Rosell R, Moran T, Queralt C, Porta R, Cardenal F, Camps C, Majem M, Lopez-Vivanco G, Isla D, Provencio M, et al: Screening for epidermal growth factor receptor mutations in lung cancer. N Engl J Med 361: 958-967, 2009.

83. Chung CH, Seeley EH, Roder H, Grigorieva J, Tsypin M, Roder J, Burtness BA, Argiris A, Forastiere AA, Gilbert J, et al: Detection of tumor epidermal growth factor receptor pathway dependence by serum mass spectrometry in cancer patients. Cancer Epidemiol Biomarkers Prev 19: 358-365, 2010.

84. Jiang B, Liu F, Yang L, Zhang W, Yuan H, Wang J and Huang G: Serum detection of epidermal growth factor receptor gene mutations using mutant-enriched sequencing in Chinese patients with advanced non-small cell lung cancer. J Int Med Res 39: 1392-1401, 2011.

85. Brevet M, Johnson ML, Azzoli CG and Ladanyi M: Detection of EGFR mutations in plasma DNA from lung cancer patients by mass spectrometry genotyping is predictive of tumor EGFR status and response to EGFR inhibitors. Lung Cancer 73: 96-102, 2011.

86. Taniguchi K, Uchida J, Nishino K, Kumagai T, Okuyama T, Okami J, Higashiyama M, Kodama K, Imamura F and Kato K: Quantitative detection of EGFR mutations in circulating tumor DNA derived from lung adenocarcinomas. Clin Cancer Res 17: 7808-7815, 2011

87. Chen YM, Fan WC, Tseng PC, Tsai CM, Chou TY, Wu CH, Chou KT, Lee YC, Perng RP and Whang-Peng J: Plasma epidermal growth factor receptor mutation analysis and possible clinical applications in pulmonary adenocarcinoma patients treated with erlotinib. Oncol Lett 3: 713-717, 2012.

88. Nakamura T, Sueoka-Aragane N, Iwanaga K, Sato A, Komiya K, Kobayashi N, Hayashi S, Hosomi T, Hirai M, Sueoka E and Kimura S: Application of a highly sensitive detection system for epidermal growth factor receptor mutations in plasma DNA. J Thorac Oncol 7: 1369-1381, 2012.

89. Goto K, Ichinose Y, Ohe Y, Yamamoto N, Negoro S, Nishio K, Itoh Y, Jiang H, Duffield E, McCormack R, et al: Epidermal growth factor receptor mutation status in circulating free DNA in serum: from IPASS, a phase III study of gefitinib or carboplatin/paclitaxel in non-small cell lung cancer. J Thorac Oncol 7: 115-121, 2012.

90. Chen ZY, Zhong WZ, Zhang XC, Su J, Yang XN, Chen ZH, Yang JJ, Zhou Q, Yan HH, An SJ, et al: EGFR mutation heterogeneity and the mixed response to EGFR tyrosine kinase inhibitors of lung adenocarcinomas. Oncologist 17: 978-985, 2012.

91. Pantel $\mathrm{K}$ and Alix-Panabières $\mathrm{C}$ : Circulating tumour cells in cancer patients: challenges and perspectives. Trends Mol Med 16: 398-406, 2010.

92. Alunni-Fabbroni M and Sandri MT: Circulating tumour cells in clinical practice: methods of detection and possible characterization. Methods 50: 289-297, 2010.

93. Punnoose EA, Atwal S, Liu W, Raja R, Fine BM, Hughes BG, Hicks RJ, Hampton GM, Amler LC, Pirzkall A and Lackner MR: Evaluation of circulating tumor cells and circulating tumor DNA in non-small cell lung cancer: association with clinical endpoints in a phase II clinical trial of pertuzumab and erlotinib. Clin Cancer Res 18: 2391-2401, 2012.

94. O'Flaherty JD, Gray S, Richard D, Fennell D, O'Leary JJ, Blackhall FH and $\mathrm{O}^{\prime}$ Byrne KJ: Circulating tumour cells, their role in metastasis and their clinical utility in lung cancer. Lung Cancer 76: 19-25, 2012. 